\title{
Haridusliku mängu mõju osalejate akulturatsioonihoiakutele
}

\author{
Ivar Männamaa $^{\mathrm{a}}$, Aurika Komsaare ${ }^{\mathrm{a}}$, Äli Leijen ${ }^{\mathrm{b}}$ \\ a Tartu Ülikooli Viljandi kultuuriakadeemia \\ ${ }^{b}$ Tartu Ülikooli haridusteaduste instituut
}

\begin{abstract}
Annotatsioon
Euroopa põgenikekriis nõuab Eesti koolisüsteemilt valmisolekut sisserändajatest õpilaste vastuvõtmiseks. Elanikkonna hoiakud mõnest muust religioossest või kultuurilisest grupist pärinevate sisserändajate suhtes pole alati pooldavad (Beilmann, 2016; Laineste, Raus, Timmi, Vetik, \& Vihalemm, 2011), ent sisserändajate peredest pärit õpilaste kohanemist kooliga mõjutab ka kaasõpilaste suhtumine. Koolikaaslaste suhtumise ja hoiakute kujundamisel on mitmes valdkonnas edukalt rakendatud mänge, ent pole teada, kuivõrd mõjutavad nende käigus omandatud kogemused õpilase hoiakuid väljaspool mängu (Chin, Dukes, \& Gamson, 2009; Wouters, van Nimwegen, van Oostendorp, \& van der Spek, 2013). Praegune uuring võimaldab hinnata mängu mõju põlisrahvusest osalejate akulturatsioonihoiakute muutumisele. Uuringus kasutati sekkumisvahendina mudeldusmängu „Allikad” (Männamaa, 2015; Männamaa, Vetik, \& Liiv, 2011), akulturatsioonihoiakuid hinnati 12 väitest koosneva küsimustiku abil. Analüüs näitas erinevust mängus osalenud õpilaste eel- ja järeltesti tulemustes $(p<0,05)$. Tulemused osutavad sellele, et eesmärgipäraselt loodud mäng võib aidata kaasa õpilaste akulturatsioonihoiakute muutumisele.
\end{abstract}

Võtmesõnad: akulturatsioonihoiakud, hariduslikud mängud, hoiakute muutumine, mudeldusmäng „Allikad”, mängupõhine õpe, teadmise ülekanne

\section{Sissejuhatus}

Eri põhjustel Aafrikast, Lähis-Idast ja Ees-Aasiast Euroopasse saabuvad põgenikud seavad nii ELi kui ka selle liikmesriikide juhtorganite ette üha uusi ülesandeid (Refugee crisis ..., 2015). Alates 2015. aasta algusest on

Tartu Ülikooli Viljandi kultuuriakadeemia, Posti 1, 71004 Viljandi; ivarman@ut.ee 
sisserändajaid saabunud üle miljoni (Europe’s Migration Crisis, 2016; Park, 2015) ning on alust arvata, et ühel või teisel moel tuleb ka Eestil olla valmis pagulase staatuse saanute lõimimiseks oma ühiskonda. Kuna põliselanikkonna hoiak uussisserändajate suhtes on tihti ettevaatlik (Ainsaar \& Beilmann, 2016; Strabac \& Listhaug, 2008), on sisserändajate vastuvõtmise kava mitmes ELi liikmesriigis, sh ka Eestis, vastuseisu leidnud (vt nt Teder, 2015). Lisakahtlusi tekitab tõik, et meie senine kogemus muukeelse elanikkonna lõimimisega pole olnud kuigi tõhus (Kus-Harbord \& Ward, 2015). Uuringute tulemused osutavad vene vähemuse segregatsioonile Eestis (Ehala \& Zabrodskaja, 2011) ning näitavad, et siin elavad venelased peavad eestlaste võimalusi ühiskonnas toimimiseks oluliselt paremaks võrreldes enda omadega (Vetik, 2015). Lisaks on Eesti venekeelse elanikkonna akulturatsioonistrateegiate väljaselgitamisel selgunud, et ainus riigi ühiskondlikus elus osalemise suhtes aktiivse hoiakuga grupp on see, keda iseloomustavad separatsiooni tunnused, näiteks tugev etniline eneseteadvus ning negatiivne hoiak Eesti riigi poliitika suhtes (Kruusvall, Vetik, \& Berry, 2009). Samas on teada, et koolikaaslaste toetav või vähemalt salliv suhtumine sisserändajatest õpilastesse võib olla kohanemise seisukohast väga oluline (Isac, Maslowski, \& van der Werf, 2012; Kosic, Mannetti, \& Sam, 2005).

Sisserändajate peredest pärit õpilaste hariduslikku lõimimist mõjutavad paljud tegurid, sealhulgas võimalikud läbielatud psüühilised traumad ja emotsionaalne stress (McCarthy, 1998), sisserännanud õpilaste ja kohalike akulturatsioonihoiakute sarnasus või erinevus (Bourhis, Moïse, Perreault, \& Senécal, 1997; Verkuyten, Thijs, \& Sierksma, 2014) ning ka põlisrahvusest kaasõpilaste akulturatsioonihoiakud (Aronson \& Brown, 2013; Isac et al., 2012; Kosic et al., 2005). Vastuvõtva riigi elanike hoiakute muutmisel on sekkumisvahenditena kasutatud nt kontakti kujutlemist, sisserändajaid soodsas valguses näitavate tekstide lugemist (Vezzali, Capozza, Stathi, \& Giovannini, 2012) ning kriitiliste juhtumite analüüsi (Herfst, van Oudenhoven, \& Timmerman, 2008), ent tulemused on olnud mitmeti tõlgendatavad. Kultuuridevahelist suhtlust puudutavatest mängudest (Fowler \& Pusch, 2010) on tuntuimad ilmselt „BaFà BaFà” (Shirts, 1995) ja „Barnga” (Thiagarajan, 2006), mis keskenduvad toimetulekule kultuurierinevustest tulenevate käitumisviiside ja/või normidega. Praeguse uurimuse tarbeks kasutasime mudeldusmängu „Allikad” (Männamaa et al., 2011), mille põhirõhk on koostöö ja võistluse dilemmal ning ühisosa leidmisel piiratud ressursside korral. Seega vaatleme samuti mängupõhist õpet (MPÕ), ent uurime selle mõju õpilaste akulturatsioonihoiakutele.

Enne mängu „Allikad” levitamist kasutati selle viimase prototüübi katsetamisel viiest väitest koosnevat küsimustikku, millega hinnati osalejate 
akulturatsioonihoiakuid. Mängu mõju hindamisel võrreldi mängus osalenud õpilaste tulemusi mitteosalenud õpilaste omadega (Männamaa $\&$ Leijen, 2015). $T$-test näitas erinevust kahe grupi hoiakutes $(t=2,354$, $d f=38,061, p=0,023)$. Kuigi küsimustik oli väga lühike ning gruppide eeltestide võrdlust ei tehtud, lubasid tulemused oletada akulturatsioonihoiakute muutumist. Mäng loeti kasutuskõlblikuks (praeguseks on selle juhendit tõlgitud enam kui kümnesse keelde), ent pidasime vajalikuks välja selgitada, kas gruppidevaheline erinevus ilmnes juhuslike tegurite toimel või oli see seotud mänguga. Kõhklusteks oli kaks olulist põhjust. Esiteks, õpiülekanne eri valdkondade vahel tundub olevat harv (Day \& Goldstone, 2012). Teiseks, MPÕ puhul on tegemist vähima suunamise strateegiaga, mille tõhusus on üldises plaanis üsna põhjendatult kahtluse alla seatud (vt nt Kirschner, Sweller, \& Clark, 2006). Et seda mõningast vastuolu selgitada, korraldasime mängu „Allikad” abil kvaasieksperimendi. Eelkõige otsisime vastust küsimusele, kas õpiotstarbelise mängu abil on võimalik mõjutada osalejate akulturatsioonihoiakuid.

\section{Akulturatsioonihoiakud}

Siinses artiklis lähtume määratlusest, mille kohaselt akulturatsioon tähendab kultuurigrupis või indiviidis toimunud muutusi, mis tulenevad kontaktidest ja suhtlemisest teise kultuurigrupiga (Berry, Poortinga, Breugelmans, Chasiotis, \& Sam, 2011, lk 475). Kuna akulturatsioon on kahepoolne kommunikatiivne protsess, on lõimunud ühiskonna poole liikumisel oluline nii sisserändajate peredest õpilaste kui ka enamuse akulturatsioonihoiakute iseloom.

Sisserännanute akulturatsioon sõltub mitmetest teguritest ning nende koostoimest. Ühena teoreetilistest mudelitest võiks kohanemist kujundavate tegurite kirjeldamiseks kasutada Kimi (2001) kommunikatsioonimudelit, mis näitab muu hulgas suhtlemise ja kontaktide olulisust kohanemisel. See mudel kirjeldab sotsiokultuurilist kohanemist laiemalt, mitte ainult haridusasutuses, andes alust eeldada, et sisserändajate perest pärit õpilase kohanemist mõjutavad ühelt poolt nende isikuomadused, sealhulgas akulturatsioonihoiakud, teiselt poolt aga kaasõpilastega suhtlemise iseloom, nende akulturatsiooni ja mitmekultuurilisusega seotud hoiakud.

Akulturatsiooniprotsessis võib nn uue ja vana kultuuri aktsepteerimisel ja omaksvõtmisel kasutada mitmesuguseid kombinatsioone. Neid kombinatsioone on nimetatud akulturatsioonistrateegiateks (Berry, 2006), hoolimata sellest, et enamasti pole tegemist läbimõeldud programmiga, vaid märkamatult kujunenud eelistustega. Ka Eesti integratsioonipoliitika 
kujundamisel aluseks võetud valdkondlikus arenduskavas (Lõimuv Eesti, 2014) on sõnastatud üheselt, et lõimumist toetavate väärtushoiakute kujundamisel on võtmeroll suhtlemisel ning pidevatel positiivsetel kontaktidel eri ühiskonnarühmade vahel.

Enim levinud akulturatsioonimaatriksis (Berry et al., 2011; Berry \& Sam, 1997) eristatakse uue ja vana omaksvõtmisest või säilimisest lähtudes integratsiooni, assimilatsiooni, separatsiooni ja marginaliseerumist. Integratsiooni iseloomustab esimese kultuuri elementide lõimimine uue kultuuri elementidega, enese seostamine mõlema kultuuriga. Assimilatsiooni puhul võtab inimene omaks uue kultuuri väärtused, seostab end eelkõige uue kultuuriga. Separatsioon tähendab distantseeritust uuest kultuurist ja enda seostamist pigem päritolukultuuriga. Marginaliseerumise puhul kaotatakse side päritolukultuuriga, sidet uue kultuuriga aga ei looda.

Et eristada akulturatsioonihoiakuid ja -strateegiaid, on neid mõnikord määratletud kui akulturatsiooni ideaalset ja reaalset tasandit (Navas, Rojas, García, \& Pumares, 2007). Seega on hoiakud seotud eeskätt arvamuste ja suhtumisega, rakendatud strateegiad on aga pigem tegevuslikud.

Mõistele akulturatsioonihoiak on sisult lähedane akulturatsioonieelistus, mida teemakohases kirjanduses samuti sageli kasutatakse (Zagefka, González, \& Brown, 2011) ning mille tähendus langeb suures osas kokku akulturatsioonihoiaku omaga. Siinses uurimuses oleme siiski keskendunud just akulturatsioonihoiakute kujunemisele, lähtudes eesti keele loogikast, kus eelistus tähendab valikuvõimaluse korral paremaks pidamist. Seega väljendab see sõna tegevusele viitavat aktiivsust, sarnanedes selle poolest pigem mõistega strateegia. Kirjanduses on selles tähenduses kasutatud ka terminit akulturatsioonikavatsus (acculturation intention) (Tartakovsky, 2012). Praeguses uurimuses keskendusime aga eeskätt küsimusele, kas kasutatud mäng mõjutab mängijate akulturatsioonihoiakuid.

Uurimustes on leitud, et dominantkultuuri esindajate hoiakud mitmekultuurilisuse ja erisuste suhtes on negatiivsemad kui sisserändajatel (Arends-Tóth \& van de Vijver, 2003; Thijs \& Verkuyten, 2014; Ward \& Masgoret, 2008). Uurijad on põhjendanud seda asjaoluga, et mitmekultuurilisus toetab sisserändajate identiteeti, kuid dominantkultuuri esindajate identiteedile mõjub see aga ohustavalt, seejuures on tajutud oht oluline tegur akulturatsioonihoiakute kujunemisel (Breugelmans \& van de Vijver, 2004; Stephan, Renfro, Esses, Stephan, \& Martin, 2005). See osutab tõigale, et sisserännanud õpilaste toimetulek koolis sõltub muu hulgas sellest, millised on kaasõpilaste akulturatsioonihoiakud. Sujuvamat kohanemist ja tõhusamat toimetulekut toetavad kaasõpilaste positiivne suhtumine ning mitmekultuurilisusele avatud hoiakud. Uuringus kasutatud mäng „Allikad” 
on loodud just mitmekultuurilisuse kui rohkemate võimaluste idee mõistmiseks ning seda toetavate hoiakute, sh mitmekultuurilisust soosivamate akulturatsioonihoiakute kujundamiseks.

\section{Mängupõhine õpe}

Mängupõhine õpe (MPÕ) kui õppemeetod on uurijate suuremat tähelepanu pälvinud juba alates möödunud sajandi kuuekümnendatest, kui oma tööd avaldasid Jerome Bruner ja Albert Bandura. Hariduslike mängude puhul, mille otstarbeks on mõne spetsiifilise õpieesmärgi saavutamine, on uuritud nii nende üldist (Wainess, Koenig, \& Kerr, 2011) kui ka spetsiifilist mõju, nt mõju kognitiivsetele võimetele ja motivatsioonile (Garris, Ahlers, \& Driskell, 2002; Rieber, Smith, \& Noah, 1998; Wouters et al., 2013) või käitumislaadile ja hoiakutele (Ruben, 1999; Wainess et al., 2011; Wilcox et al., 2008). Hoolimata lähenemisnurgast on selge, et haridusliku mängu üheks otstarbeks on toetada õppimist. Samamoodi nagu teised meetodid peaks ka MPÕ päädima osalejate valmidusega uut moodi reageerida. MPÕ puhul tuleb arvestada sellega, et osalejad peavad olema valmis omandatud teadmisi ja/või oskusi edaspidi rakendama õpisituatsioonist erinevas olukorras. (Isegi kui mõne simulatsiooni korral on õpikeskkond võimalikult reaalse ülesande sarnaseks tehtud, ei ole kõiki tunnuseid, nt lõhnasid või emotsioone, siiski alati võimalik jäljendada). Õppija võimet kasutada ühes kontekstis omandatut uudses kontekstis esineva ülesande lahendamisel tuntakse õpiülekandena (Perkins \& Salomon, 2012; Simons, 1999).

\section{Õpiülekanne mängupõhises õppes}

Kuigi õpiülekannet on viimastel kümnenditel üsna intensiivselt uuritud, ei ole ikka üheselt selge, millistel tingimustel see toimub ja millistel mitte. Hoolimata üha keerukamatest eksperimentidest tundub õpiülekanne „haihtuvat kohe, kui teadlane seda lähemalt uurima asub" (Schoenfeld, 1999, lk 7). Nagu kõigi teiste õpimeetodite kasutajad, soovivad ka hariduslike mängude läbiviijad, et osalejad suudaksid mängu käigus õpitut rakendada teistlaadses, mängust erinevas kontekstis. Nii näiteks oleks huvitav teada, kas sissejuhatuses mainitud mängus „Barnga” osalenud sõjaväelane oskab mängust saadud teadmist/kogemust tõepoolest kasutada ka kultuurierinevustest tuleneva reaalse konflikti korral või kas vangi dilemmal (Akin, 2015) rajanevas mängus osalenute koostöövalmidus suureneb.

Õpiülekannet on määratletud ka spetsiffilisemate kriteeriumide kaudu, nt kui uudsete representatsioonide moodustamist varasemate teadmiste 
valikulise aktiveerimise abil (Nokes-Malach \& Mestre, 2013) või kui olemasoleva teadmise modifitseerimist uudse ülesande lahendamisel (Hung, 2013). Kuigi mõned autorid (Hager \& Hodkinson, 2009) on leidnud, et teadmise ülekande ja teadmise omandamise eristamine ei ole üldse viljakas ning sellest tuleks loobuda, on valdavam siiski arvamus, et ülekanne on õppimise möödapääsmatu eeltingimus ning seega igasuguse õppeprotsessi üks põhiküsimusi (McDaniel, 2007). McDaniel näitab ka, kui oluline on ülekanne õpiprotsessi hindamisel, iseäranis mängu- ja simulatsioonipõhise õppe loojate ja kasutajate jaoks.

Mõned uurijad leiavad, et olenevalt sellest, kuivõrd sarnaneb õpisituatsioon ülekannet eeldava situatsiooniga, tuleb eristada kahte tüüpi õpiülekannet: lähedast ja kauget (Chi \& VanLehn, 2012; Kaminski, Sloutsky, \& Heckler, 2013). Seda tüüpi jaotus eeldab, et ülekande puhul eristatakse õpitu sisu ja konteksti. Selliste telgedega taksonoomia on välja pakkunud Barnett ja Ceci (2002), näidates veenvalt, mille poolest erinevad üksteisest sisu (mida üle kantakse) ning kontekst (kust ja kuhu üle kantakse). Teise võimalusena eeldatakse (nt Day \& Goldstone, 2011), et ülekanne põhineb nende tõikade või seoste otsesel sarnasusel, mis esinevad õppimisel kasutatud ülesandes või lahendust vajavas probleemis, mistõttu on olemuslikult võimalik üksnes lähiülekanne. Vastandina sellisele pindmisele, elementide sarnasusel rajanevale hüpoteesile nähakse ka nn printsiibilist või skeemipõhist võimalust, kus ülekande aluseks on elementidevaheliste suhete kokkulangevus (Helfenstein, 2005). Skeemipõhiste lähenemisviiside kohaselt võivad ülekannet põhjustada ka üldisemad seosed, mis rajanevad analoogial või kontekstilisel seosel, sõltumata seejuures valdkondade sarnasusest (Rosalie \& Müller, 2014). On ka arvatud, et kuigi ülesannetes esinevate elementide otsest (pindmist) sarnasust on õpilasel hõlpsam meenutada, on uut tüüpi ülesande lahendamisel siiski rohkem kasu just skeemipõhisest kokkulangevusest (Ross, 1989).

Praeguses uurimuses kasutatud mängu puhul eeldasimegi just skeemipõhist kaugülekannet, sest õppijalt oodatakse, et ta mõistab mängu käigus koostöö ja võistluse põhimõtet ning muudab selle mõjul oma akulturatsioonihoiakuid. Kõnealuse mängu rakendamisel pole eesmärgiks seatud tegelikkuse võimalikult täpne kajastamine üksikelementide tasandil, mida taotletakse paljudes simulatsioonides, nt meditsiinilistes (Tun, Alinier, Tang, \& Kneebone, 2015), vaid pigem referentssüsteemis esinevate toimijate ja vahendite (agentide ja ressursside) ning nendevaheliste seoste abstraheerimine tasemeni, mis oleks ühtmoodi hoomatav eri taustaga mängijate rühmale. Kui puhta simulatsiooni puhul on raskuspunkt konteksti ülekandel (nt mulaaž kunstliku hingamise õppimiseks), siis meta- 
foorse mängu rakendamisel on tähtis sisu ülekanne. Esimesel juhul on tegelikkusega võimalikult sarnaseks disainitud harjutuse rutiin, teisel juhul aga ülesande lahendamiseks vajalik sisuline printsiip (selle näitlikustamiseks sobib paberi voltimise (paper fold) ülesanne, mille abil tutvustatakse õpilastele eksponentsiaalse kasvu põhimõtet (Meadows, 1999)). Sestap saame eeldada, et üht või teist tüüpi ülekandega - kas sisu- või kontekstiülekandega - tuleks arvestada ka mängupõhise õppe kavandamisel, kuigi mõlemal juhul toimub õppimine üsna üheselt mõistetavalt tegevuse ja selle kaudu omandatud kogemuse vahendusel.

\section{Õpiülekande soodustajad hariduslikus mängus}

Nagu eespool nägime, on ülekande toimumiseks vaja kas lähte- ja sihtülesande pindmist sarnasust või siis mõningast struktuurset kokkulangevust. Sellele üldprintsiibile lisaks on leitud mitmeid ülekannet soodustavaid lisatingimusi. Näiteks on arvatud, et õppuril peab olema piisavalt võimalusi oma esmase lahenduse katsetamiseks eri situatsioonides (Mayer, Dale, Fraccastoro, \& Moss, 2010) ning ülesanne peaks võimaldama piisava abstraktsusega skeemide kujunemist (Lobato, 2012). Ka on näidatud, et lähteülesande abstraktsus võib ülekandele avaldada soodsamat mõju kui liigne konkreetsus (Kaminski et al., 2013). Loend ei ole kindlasti ammendav ning on selge, et õppija võime kasutada omandatud teavet uudses olukorras ei avaldu iseenesest. Ainuüksi mänguga seonduva uudse teabe omandamine ja selle rakendatavaks muundamine eeldavad keerukat kognitiivset töötlust ning teisi kõrgema taseme kognitiivseid oskusi (Hung, 2013). Seega on põhjust küsida, mis spetsiifilised tegurid võiksid haridusliku mängu vahendusel toimunud õppe korral ülekannet soodustada.

Üks tegureid on ilmselt keskendumine vaid kahele-kolmele spetsiifilisele printsiibile. Kui mängu loomisel keskendutakse n-ö künnismõistetele (vt nt Barradell, 2013), siis seab see teadmiste valdkonnale selged piirid ning loob eelduse mängu abil edasiantava sisu mõistmiseks. Enamasti ei väida uurijad, et uudse teadmise omandamiseks või hoiakute muutumiseks piisab vaid selliste künnismõistete valdamisest, pigem rõhutatakse, et künnismõisted võimaldavad mõista ja kasutada ümbritsevat teavet (nt Dudai, 2007) ning seda uudsel moel tõlgendada (Davies \& Mangan, 2008). Need on kui mõttelised pääsuteed uue teadmise juurde (Meyer \& Land, 2005). Praeguse uurimuse kontekstis on oluline, et üldiselt peetakse künnismõisteid püsivaiks: kui need on kord omandatud, siis mõjutavad need õppija arusaamist teemast pikema aja jooksul ja olulisel määral. Ühel või teisel moel lähtuvad künnismõistete uurijad nn skeemi-teooriast (Bartlett, 1932), 
mis peab mälu ja seetõttu ka õppimise võtmeküsimuseks mõistevõrgustiku kujunemist. Kui eeldame, et sellises võrgustikus on mingi mõiste või arusaam, mis toimib kriitilise sõlmena, siis võib MPÕ tõhusust põhjendada keskendumisega just sellele mõistele.

Teiseks võib oletada, et järgneva ülesande sooritust parandav teadmise ülekanne eeldab mõningast valdkondadeülest nihet mõtlemises. Sellise nihke ilmestamiseks kasutatakse tihti nn kahe küla võrdlust: kui teame, kus paiknevad kirik ja kõrts ühes külas, siis hõlbustab see meil kiriku ja kõrtsi leidmist ka sootuks erineva valla külades. Kuna hariduslikud mängud on suuremal või vähemal määral metafoorsed juba tänu oma stsenaariumist tulenevale kontekstile, siis võib arvata, et selline kiriku ja kõrtsi leidmise printsiip võib ka nende puhul teadmise ülekannet soodustada. Lakoff ja Johnson (1980) väidavad, et metafoori puhul ei olegi tegemist üksnes lingvistilise nähtusega, vaid pigem ühe võimaliku mõtlemise operatsiooniga, mis võimaldab meil üht valdkonda teise abil mõtestada. Lakoff (1993) märgib, et enamasti iseloomustab metafoori suur hulk teistesse valdkondadesse viivaid seoseid ja ühendusi ning teadmise aluseks olevad abstraktsed mõisted määratletakse erinevate metafooride ühistöös, kus iga metafoor kirjeldab kindlat osa definitsioonist. Sellest tõigast tulenebki teine lähtekoht, mille abil võiks haridusliku mängu tõhusust põhjendada. Kui uued mõisted ja hoiakud kujundatakse metafooride abil, siis võib just mängu metafoorsus uue teadmise või hoiaku kujunemisele kaasa aidata.

Haridusteadustes suhtutakse metafoori kasutamisse erinevalt. Ühes äärmuses on arvamus, et metafoorid soodustavad õppimist, hõlbustades uue teabe mõtestamist ja ülekannet tuntud valdkonnast vähem tuntusse (Petrie \& Oshlag, 1993). Teisalt on arvatud, et tegemist on lihtsakoelise heuristikaga, mida õppija kasutab juhul, kui ta ei vaevu piisavalt vaeva nägema, et põhjalikumalt analüüsida ja sõnastada, mida ta täpselt öelda tahab (ibid., lk 580). See seisukoht on kooskõlas Kahnemani hüpoteesiga, mille kohaselt lähtub inimene probleemide lahendamisel kas aeglasest või kiirest mõtlemisest. Kahneman (2011, lk 171) viitab ühele Nisbetti ja Borgida varasemale uuringule, kus tudengitele esitati kas mõni üllatav statistiline tõik või seda tõika ilmestava üksikjuhtumi kirjeldus (nt möödakäijate ootamatult vähene valmidus vastata tänaval lamava inimese abipalvele). Esimesel juhul (kui esitati statistiline tõik) ei õppinud tudengid justkui midagi, sest nad polnud võimelised seda üldist teadmist üksikjuhtumile üle kandma. Kui aga tudengeile tutvustati esmalt üksikjuhtumit, siis kandsid nad selle teadmise üsna täpselt üle ka populatsioonile tervikuna. Nisbetti ja Borgida sõnul (viidatud Kahneman, 2011 järgi) on õppija soovimatus tuletada üldisest üksikut kooskõlas üksnes sooviga teha üksiku põhjal järeldusi üldise kohta. Sarna- 
seid tulemusi on andnud ka uuringud, kus üks rühm omandab teoreetilist teavet, sellal kui teine rühm tutvub samade probleemidega tegeliku loo kaudu. Tulemused lubavad järeldada, et teine rühm oskab omandatud teavet uudses olukorras tõhusamalt kasutada (Perkins \& Salomon, 2012).

\section{Mängu abil õppimise kitsaskohad}

Kuigi Kolbi kogemusõppe mudelit (Kolb, 1984) on mitmest aspektist õigustatult kritiseeritud (Bergsteiner, Avery, \& Neumann, 2010; Coffield, Moseley, Hall, \& Ecclestone, 2004), domineerivad õppimise suunamises senini kaks vastandlikku lähenemisviisi. Ühest küljest seatakse hüpotees, mille kohaselt õppimine on tõhusaim vähima suunamise puhul: õppureil tuleb olulisim teave iseseisvalt leida ja selle alusel uus teadmine moodustada. Teine hüpotees eeldab, et just teema seisukohalt algajad õppurid, kellega mängupõhise õppe puhul tuleb tihti arvestada, vajavad abstraktsete mõistete ja tehete omandamisel eelkõige vahetut suunamist. Mitmed katsed on selgelt näidanud, et uudse teabe korral on õppimine tõhusam, kui õppijatele näidatakse täpselt, mida ja kuidas ülesande lahendamisel tuleb kasutada (Kirschner et al., 2006). Seega oleks loogiline eeldada vähima suunamisega õpikeskkondade (sealhulgas MPÕ) väiksemat tõhusust, sest kognitiivse ülekoormuse hüpoteesi kohaselt võib „keeruka keskkonna iseseisva tundmaõppimisega kaasneda töömälu ülekoormamine, mis vähendab õppimise tõhusust" (ibid., lk 80). Kuna mängude või simulatsioonide puhul tuleb korraga tegeleda nii mängu reeglistikust kui ka õpisisust tulenevate mõistete ja skeemidega, võib osalejatel esineda kognitiivse ülekoormuse probleem.

Eelöeldu põhjal võiks kahelda mängupõhise õppe tulemuslikkuses, sest raske on vaielda loogikaga, mille kohaselt a) õpitu salvestub pikaajalisse mällu; b) pikaajalisse mällu jõuavad teadmised lühiajalise mälu vahendusel; c) lühiajalise mälu maht on piiratud; d) mängukeskkonnas orienteerumine hõivab suure osa lühiajalise mälu mahust ning e) mängu tegelikku õpisisu salvestub seetõttu oodatust vähem. Lühidalt öeldes sunnib mäng kui õpikeskkond õppijat teavet töötlema ja mõistetega opereerima moel, mis ei ole õpisisuga seotud. Suur hulk teabest ja mõistetest kohalduvad üksnes mängu reeglitest tulenevale ning on seatud õpieesmärke arvestades ebaolulised või isegi nende saavutamist pärssivad. Kuna meie töömälu ressursid on piiratud, võib mingi hulk tarvilikke mõisteid ja seoseid jääda märkamata ning järelikult ka omandamata.

Peale kognitiivse ülekoormuse seisab haridusliku mängu rakendaja silmitsi veel mitme takistusega, mis võivad mängu õnnestumist ohustada. On näidatud, et isegi kui mäng on hästi koostatud, ei pruugi see soovitud 
tulemuseni viia, kui mängu juhtimine on nõrk, mängule järgnev arutelu puudulik või tekib n-ö lustiva inimese lõks (Homo ludens pitfall), mille korral lasevad osalejad end mängust liialt kaasa haarata (Hofstede, de Caluwé, \& Peters, 2010). Lähtudes tõigast, et isegi hästi koostatud mäng võib näiteks eelkirjeldatud põhjustel ebaõnnestuda, on äärmiselt oluline, et kõikide hariduslike mängude ja simulatsioonide puhul oleks korraldatud ka põhjalikum uuring, mis võimaldab nende võimalikku tõhusust hinnata. Seega on ka meie esmane uurimisküsimus seotud eelkõige konkreetse mängu tõhususega: kas soovitud muutus osalejate akulturatsioonihoiakutes toimub või mitte? Mõningate mööndustega võib ka väita, et kui hoiakute muutus leiab mängu mõjul aset, siis saame mängu abil demonstreerida ka sisu ülekannet ühest kontekstist teise. Varasemaid õpiülekande uuringuid arvestades saame arutleda ka võimalike tingimuste üle, mis võivad MPÕs õpiülekannet soodustada.

\section{Meetod}

Uurimisküsimusele vastamiseks kavandasime kvaasieksperimendi, mille abil saab tuvastada mängu võimalikku mõju osalejate akulturatsioonihoiakutele. Sekkumisvahendina oli kasutusel õpiotstarbeline mäng „Allikad”, mis on mõeldud kasutamiseks tavapärases õpikeskkonnas ilma arvuti või nutiseadmete abita. Mäng kestab kokku umbes 100 minutit ja koosneb kolmest osast: teavitus (ingl briefing 'mängueelne tutvumine reeglite, rollide ja mänguvahenditega'), mäng ning järelarutelu (ingl debriefing 'mängujärgne arutelu rollidest vabanemiseks, toimunu mõtestamiseks ja õpitu üldistamiseks'). Osalejate soovituslik arv on 6-24. Uuringus kasutasime aastatel 2014-2015 korraldatud mängusessioonide põhjal kogutud andmeid.

Et hinnata hoiakute muutumist, koostasime 12 väitest koosneva küsimustiku, millele katserühma liikmed vastasid vahetult enne mängu ning seejärel umbes kaks nädalat hiljem. Eel- ja järeltest viidi läbi nii katserühmas (osalesid mängus) kui ka kontrollrühmas (ei osalenud mängus). Kuna uuring tehti tavapärase õppetöö raames, ei saanud osalejaid katse- ja kontrollrühma jaotada juhuvaliku alusel. Kontrollrühma moodustamisel lähtuti eeldusest, et rühma liikmed õpivad sarnase õppeprogrammi alusel ning nende demograafilised näitajad on sarnased katserühma liikmete omadega. 


\section{Osalejad}

Kokku osales uuringus 138 inimest (keskmine vanus 18). Kasutada oli võimalik 131 osaleja andmeid (vt tabel 1), puudulikult täidetud küsimustikke analüüsi ei kaasatud. Kõik osalejad valdasid vabalt eesti keelt.

Tabel 1. Osalejate andmed

\begin{tabular}{l|c|c|c|c}
\hline Rühm & $n$ & Rühmade arv & Vanus $M(S D)$ & Sugu (M/N) \\
\hline Katserühm & 82 & 6 & $18,5(1,61)$ & $22 / 60$ \\
\hline Kontrollrühm & 49 & 4 & $17,8(1,66)$ & $17 / 32$ \\
\hline KOKKU & 131 & 10 & $18,2(1,72)$ & $39 / 92$ \\
\hline
\end{tabular}

Nii katse- kui ka kontrollrühm (vastavalt $n=82$ ja $n=49$ ) olid samadest õppeasutustest, võimaluse korral kaasasime uuringusse määratud teeninduspiirkonnaga koolide paralleelklassid või õpperühmad. See lubab arvata, et osalejad olid sarnase etnilis-kultuurilise taustaga ning õppisid sarnase õppekava alusel. Kuna valimid kujunesid paralleelklasside õpilastest, ei moodustunud need siiski juhuslikkuse alusel.

\section{Materjalid}

Sekkumiseks kasutatud mäng „Allikad” loodi Integratsiooni ja Migratsiooni Sihtasutuse (www.meis.ee) tellimusel õpiotstarbelise vahendina, mis aitab mõista kultuurilise integratsiooni protsesse. ${ }^{2}$ Mängu disain rajaneb kahemõõtmelisel akulturatsioonimudelil (Sam \& Berry, 2010), kus üks telg kajastab soovi oma kultuurilist eripära alal hoida ja tugevdada ning teine telg soovi osaleda ühiselulistes protsessides ja otsuste vastuvõtmises. Mäng sisaldab ka koostöö ja võistluse dilemmat piiratud ressursside tingimustes, sarnanedes selle poolest Garrett Hardini (1968) ühisvara tragöödia skeemiga.

Mäng on üles ehitatud akulturatsioonistrateegiate põhjal. Osalejatel tuleb piiratud ressursside tingimustes toimides hoolitseda oma rühma vajaduste eest ning pidada samal ajal silmas ka teiste rühmade huve. Mängu aluseks olev mudel sisaldab kahte põhilist komponenti: oma leviala laiendada soovivaid rühmi ja ühiskasutatavaid ressursse, mille kestlik kasutamine eeldab ühistegevust. Alarühmad saavad igas mänguvoorus rakendada

Mängu aluseks oleva mudeli täpsema kirjelduse on avaldanud Männamaa ja Leijen (2015), mängija juhend koos juhistega mängu läbiviimiseks on avaldatud iseseisva artiklina (Männamaa, 2015). 
laienemispotentsiaali, seevastu ressursside juurdekasv sõltub üksnes osalejate valitud strateegiatest. Kui osalejad on orienteeritud pigem võistlusele kui koostööle, pidurduvad nii alarühmade laienemine kui ka ressursside juurdekasv. Mängutulemuse parandamiseks on seega võimalik valida erinevaid strateegiaid, mille tulemuslikkuse üle arutletakse mängujärgse arutelu ajal.

Mängus „Allikad” osalejatel tuleb oma käikude sooritamisel peaasjalikult tegeleda probleemiga, mis tuleneb kahest integratsiooniprotsessi mõneti vastandlikust tingimusest. Esiteks tuleb säilitada ja tugevdada oma identiteeti (võimaldab mänguskoori kasvatada) ning teiseks on vaja osaleda otsuste langetamises (nii nagu päriselus annab see ka kõnealuses mängus parema ligipääsu ressurssidele). Kuna tõhusaimaks akulturatsioonistrateegiaks peetakse lõimumist (Sam \& Berry, 2010), siis võib ratsionaalselt käituv mängija ka mängus „Allikad” lahendada kaks eelkirjeldatud vastuolu lõimimisstrateegia abil. Et mängija ei saaks strateegia valikul lähtuda pelgalt ratsionaalsest otsustusest, on mängu lisatud haavatavusest ja konfliktist tulenevad piirangud, mis kaasnevad akulturatsiooniprotsessiga reaalses elus.

Haavatavusest tulenev piirang on mängu lisatud tingimusega, mille kohaselt on lõimimisstrateegia kõige ahvatlevam siht võimalikele ründajatele. Kuigi puhtmatemaatiliselt oleks lõimumine kõige tõhusam, väheneb konfliktsituatsioonis allajäämise korral mänguskoor tuntavalt. Seevastu konfliktist tulenev piirang avaldub umbes $45 \%$ tõenäosuses, et konfliktis kaotavad mõlemad pooled. Teisisõnu, kuigi võistlus võib esmapilgul tunduda otstarbeka strateegiana, lõpeb see pea pooltel juhtudel mõlema osalise kaotusega. Niiviisi kujuneb nullsumma mängu asemel miinussumma mäng, kus mõlemal osalejal on küll ühiseid huvisid, ent ometi on lõpptulemus sõltumatute otsuste puhul mõlema jaoks negatiivne, nagu see ka tegelikus elus etniliste või religioossete konfliktide puhul tihti on (vrd hiljutised konfliktid Põhja-Aafrikas ja Ees-Aasias). Seega on tegemist metafoorse mänguga, mille käigus õpitut on võimalik üle kanda mitmesugustesse eluvaldkondadesse. Mängu põhieesmärk on kujundada akulturatsioonihoiakuid, sest reeglistikust tulenevad tingimused ja piirangud - oma identiteedi säilitamine ja otsustusprotsessides osalemine tingimustes, kus on oht muutuda liiga haavatavaks või sattuda negatiivse tulemiga konflikti - on olemuslikud ka akulturatsioonile. Seega võib eeldada, et akulturatsioonihoiakud võivad mängu „Allikad” mõjul muutuda.

Mudeldusmäng „Allikad” on metafoorne ka mängukomplekti kuuluvate elementide poolest, sest mängulaua tasapinnalistel trapetsi- ja kuusnurgakujulistel elementidel ei ole otsest seost ei kultuuriliste ega etniliste rühmade või nendevaheliste suhetega. Mängijate ülesanne on paigutada mängunupud 
lauale nii, et kogutaks võimalikult palju punkte. Mängijad (või mängivad võistkonnad) esindavad kuut rühma (hõimu), kes peavad viima oma hobused mängulaual olevate allikate juurde jooma. Iga allika juures on kuus joogikohta, igas mänguvoorus tuleb mängijail paigutada oma hobused vabadele joogikohtadele. Tehes seda kindlal moel, on võimalik preemiana mänguväljal ka uusi allikaid avada. Hobuste paigutusest allikate juures sõltub see, kui palju punkte mängija teenib. Näiteks juhul, kui ühtegi joogikohta pole võimalik kasutada, võib mängija algatada võistluse, et sundida teise mängija hobuseid allika juurest lahkuma. Võistlus lahendatakse kahe täringu viskega, mis võib viia ka mõlema mängija kaotuseni. Mängu võidab mängija, kes on suutnud oma hobused allikate juurde paigutada viisil, mis annab enim punkte.

\section{Küsimustik}

Osalejate akulturatsioonihoiakute hindamiseks koostasime 12 väitest koosneva originaalküsimustiku, millele vastamiseks kulus osalejatel umbes 10 minutit. 5 väidet 12st olid esitatud pööratud kujul, vastamisel kasutati Likerti skaalat vahemikus 1-10 („Üldse pole nõus” ja „Täiesti nõus” kui äärmuspunktid). Küsimustiku koostamise aluseks oli varasemas uuringus (Männamaa \& Leijen, 2015) kasutatud ankeet, mida täiustasime ekspertidelt saadud näpunäidete järgi. Küsimustiku näivat valiidsust kontrollisime nii mängus osalenute kui ka ekspertide hinnangute abil.

Kasutatud väited jagunesid akulturatsiooni põhidimensioonide alusel nelja kategooriasse. Et kontrollida kaugülekande toimimist, puudub väidetel vahetu seos mängu sisuga, ent seoselist kokkulangevust on võimalik tuvastada. Kategooriad (nn üldprintsiibid, millest iga kohta oli koostatud kolm väidet) olid järgmised:

- 1. kategooria: et tagada oma rühma (kultuuri) hea käekäik, tuleb peale oma huvide kaitsmise leida ka ühisosa teiste osalistega (pööratud näidisväide: „Eesti riigil tuleb edu saavutamiseks arvestada eelkõige eestlaste huvidega, vähemuste vajadused on vähem tähtsad");

- 2. kategooria: ligipääs olemasolevatele ressurssidele võib koostöö puhul paraneda ka siis, kui rühmadevahelised piirid ei hägustu (pööratud näidisväide: „Kui Eestis elavad vähemused oma rahvuslikest eripäradest ei loobu, siis tuleb neil leppida eestlastest napimate võimalustega");

- 3. kategooria: lõimumise puhul tuleb ühe tegurina arvestada osalejate sooviga osaleda oluliste otsuste langetamises (näidisväide: „Vähemusrahvused tuleks kaasata riigi jaoks oluliste otsuste langetamisse, sest see on ka eestlaste huvides"); 
- 4. kategooria: ühiskonna lõimumisega kaasnevad paratamatult konfliktid, mille ühepoolne lahendamine võib osutuda väga kulukaks (pööratud näidisväide: „Eesti kultuuri säilitamiseks võiks olulisemad avalikud ressursid (haridus, töökohad jne) olla valdavalt eestlaste käsutuses").

Uuring põhineb eel- ja järeltesti meetodil, sekkumine (mäng) toimus vahetult peale eeltesti sooritamist. Kokku korraldati seitse mängusessiooni, eel- ja järeltestis oli kasutusel sama küsimustik. Andmed koguti kahe mängujuhi läbiviidud mängude põhjal, mis suurendab läbiviijaga seotud reliaablust. ${ }^{3}$ Mõlemad mängujuhid kasutasid identseid mänguvahendeid, sarnased olid ka mängutsükli läbimise protseduurid (sh teavitus ja järelarutelu) ning mänguks keskmiselt kulunud aeg.

Osalejad täitsid küsitluse käsitsi. Eeltesti ankeedid jagas laiali mängu läbiviija, järeltesti tegemise korraldasid üldjuhul aineõpetajad oma ainetundides või loengutes. Uuringu hüpoteese enne testide laekumist õpetajatele üksikasjalikult ei tutvustatud.

\section{Tulemused}

Andmeanalüüsis kasutasime esmalt küsimustiku üldskoori. Küsimustiku sisereliaablus oli suur $(\alpha=0,78)$, tugev oli ka eel- ja järeltesti korrelatsioon $(r=0,61)$. Kvaasieksperimendi sõltumatu muutuja oli osalemine mängus, sõltuv muutuja küsimustiku koguskoor. Andmeid töötlesime programmiga R (R Core Team, 2013). Eel- ja järeltesti tulemuste võrdlemisel kasutasime paariviisilist $t$-testi, katse- ja kontrollrühma eeltestide võrdlemisel Welchi kahe valimi testi. Katse- ja kontrollrühma eeltestide tulemused valimite erinevust väita ei luba $(t=0,62, d f=87,56, p>0,53)$. Eel- ja järeltesti võrdlus rühmade kaupa on toodud tabelis 2 .

Tabel 2. Eel- ja järeltesti võrdlus

\begin{tabular}{|l|c|c|c|c|c|c}
\hline Rühm & $n$ & $\begin{array}{c}\text { Eeltest } \\
M(S D)\end{array}$ & $\begin{array}{c}\text { Järeltest } \\
M(S D)\end{array}$ & $t$ & $d f$ & $p$ \\
\hline Katserühm & 82 & $5,78(1,18)$ & $5,97(1,23)$ & $-1,73$ & 81 & 0,043 \\
\hline Kontrollrühm & 49 & $5,63(1,41)$ & $5,55(1,35)$ & 0,44 & 48 & 0,660 \\
\hline
\end{tabular}

Näeme, et $t$-test osutab katserühma liikmete hoiakute muutumisele peale mängu $(p<0,05)$, ent kontrollrühma eel- ja järeltesti tulemuste vahel eri-

Osaliselt on andmeid varem kasutatud ühes Tartu Ülikooli Viljandi kultuuriakadeemia lõputöös (vt Väli, 2014). 
nevust ei ilmne $(p>0,66)$. Katserühma eel- ja järeltesti vaheline erinevus viitab sisuliselt sellele, et osalejate akulturatsioonihoiakud on mängu mõjul muutunud integratsioonistrateegia suhtes pooldavamaks.

Nagu eespool öeldud, koostati väited nelja kategooria alusel. Et kontrollida väidete jaotumist samadesse kategooriatesse, tegime eeltestide tulemuste põhjal faktoranalüüsi (peakomponentide meetod, telgede oblimin-pööre). Kaiseri kriteeriumile vastav omaväärtus lubas eristada kolme faktorit.

Tabel 3. Väidete laadumine faktoritesse (laadumine $>0,50$ )

\begin{tabular}{l|c|c|c|c|c|c|c|c|c|c|c|c|c}
\hline & v1 & v2 & v3 & v4 & v5 & v6 & v7 & v8 & v9 & v10 & v11 & v12 & Kaal \\
\hline F1: põlisrahvus & 0,67 & & & 0,82 & 0,55 & & & & 0,69 & 0,64 & & & 2,63 \\
\hline F2: muulased & & & 0,74 & & & 0,68 & 0,53 & 0,66 & & & & 0,62 & 2,28 \\
\hline F3: teadmised & & 0,55 & & & & & & & & & 0,64 & & 1,38 \\
\hline
\end{tabular}

Kuigi põhjalikuks faktoranalüüsiks on valim liiga väike, näitab esialgne analüüs, et väited ei jaotu küsimustiku aluseks olnud kategooriatesse. Tabelis 3 on esitatud väidete laadungid faktorite kaupa. Mängu mõjul toimusid muutused vaid teises faktoris $(t=-2,077, d f=81, p<0,02)$, esimese ja kolmanda faktori puhul $t$-test erinevust ei näita (vt tabel 4 ).

Tabel 4. Eel- ja järeltesti võrdlus faktorite kaupa

\begin{tabular}{l|c|c|c|c|c}
\hline Rühm & & $\begin{array}{c}\text { Eeltest } \\
M(S D)\end{array}$ & $\begin{array}{c}\text { Järeltest } \\
M(S D)\end{array}$ & $t$ & $p$ \\
\hline $\begin{array}{l}\text { Katserühm } \\
(d f=81)\end{array}$ & $\mathrm{F} 1$ & $17,32(5,67)$ & $18,18(5,94)$ & $-1,47$ & 0,07 \\
\cline { 2 - 6 } & $\mathrm{F} 2$ & $19,38(4,50)$ & $20,26(4,33)$ & $-2,08$ & $\mathbf{0 , 0 2}$ \\
\cline { 2 - 6 } & $\mathrm{F} 3$ & $7,78(2,06)$ & $7,59(1,65)$ & 0,81 & 0,79 \\
\hline $\begin{array}{l}\text { Kontrollrühm } \\
(d f=48)\end{array}$ & $\mathrm{F} 1$ & $15,75(6,42)$ & $15,14(5,94)$ & 0,65 & 0,52 \\
\cline { 2 - 6 } & $\mathrm{F} 2$ & $20,11(5,60)$ & $20,27(4,78)$ & $-0,22$ & 0,82 \\
\cline { 2 - 6 } & $\mathrm{F} 3$ & $7,42(2,08)$ & $7,22(2,06)$ & 0,59 & 0,57 \\
\hline
\end{tabular}

Esimese faktori („Põlisrahvus”) moodustavad vastused väidetele, mis on esitatud pigem dominantrühma (praegusel juhul eestlaste) positsioonilt, nt v4 „Eesti kultuuril läheb paremini, kui olulisemad avalikud ressursid (haridus, töökohad) on eestlaste käes”. Teise faktorisse („Muulased”) laaduvad vastused väidetele, mis on esitatud vähemusrahvuse huvidest lähtudes, nt v8 „Ka juhul, kui Eestis elavad vähemusrahvused soovivad oma keelelisi 
ja kultuurilisi eripärasid säilitada, on neil eestlastega võrdsed võimalused”. Kolmandasse faktorisse („Teadmised”) laadub kaks väidet, mis on teistest konkreetsemad ning võivad viidata pigem teadmistele põhjuse ja tagajärje seoste kohta kui hoiakutele, nt v2 „Kui eestlased mõned avalikud huvid ainult endale hoiavad, võib see põhjustada rahvustevahelisi konflikte".

Seega näitasid esialgsed tulemused kokkuvõtlikult, et mängu mõjul toimus muulaste positsiooni arvestamisega seotud väidete puhul positiivne muutus.

\section{Arutelu}

Tulemused näitavad, et mängul on mõningane mõju osalejate akulturatsioonihoiakutele, faktoranalüüsi tulemused vajavad aga edasist põhjalikumat uurimist. Suurema valimi kasutamine võimaldaks akulturatsioonihoiakute alaosi täpsustada, mis annab hea aluse mängu edasiseks kalibreerimiseks ja/ või mängujärgse arutelu muutmiseks. Mängu juhendi kohaselt sõnastavad osalejad mängu kestel toimuva lühiarutelu käigus põhimõtteid, mille järgimine aitab nende hinnangul mängus paremat tulemust saavutada. Kuigi mängijaid üldjuhul enne mängu algust selle tegelikust õpisisust ei teavitata, sõnastavad nad enamasti printsiipe, mis toetavad akulturatsiooni lõimumisstrateegiat (nt „Ära hõiva ressursse, mida sul ilmtingimata tarvis pole”; „Ära algata konflikti esimesena”; „Leia võimalusel koostööpartnereid teiste hõimude seast"). Ka see kinnitab kaudselt väidet, et mäng võiks muuta akulturatsioonihoiakuid soovitud suunas.

Kuigi uurimuse eesmärk ei olnud tuvastada võimalikke põhjuseid, mis soodustavad mängu „Allikad” mõjul õpiülekannet, saab mängu mõju mitmeti seletada. Esiteks on võimalik, et emotsioonid, mis mängupõhises õppes on tugevamad kui nn tavapärases õppes, hõlbustavad omandatud teadmise hilisemat meenutamist. Teiseks võib küsimustiku teistkordne esitamine toimida omalaadse vihjena, mis aitab varasema kogemuse abil saadud teadmist uude olukorda üle kanda. Kolmandaks võib mänguolukorras avalduda nn juhtum seaduspära vastu efekt, mille korral toimib mäng spetsiifilise juhtumina, mis hõlbustab üldise seaduspära mõistmist. Neljas võimalus on seotud künnismõistetega, mida on tavapärase õppe käigus keeruline omandada. Mängu disaini aluseks olevad skeemid - vajadus oma identiteeti kaitsta ja tugevdada ning tagada seejuures ka osalemine otsustustes - on tuletatud akulturatsiooniprotsessi kahemõõtmelisest käsitlusest. Nendest tulenev võistluse-koostöö dilemma ning vajadus ressursse üksteisega jagada võisid osalejatel põhjustada küll pinnapealse, ent siiski ajas kestva mõttenihke, mis avaldus ka järeltestide täitmisel. Viiendaks on 
võimalik, et mängus osalemine kujundas mängijate jaoks uue metafoori: hobused ja allikad. Järelküsitlusele vastates suunas see metafoor neid n-ö õigete vastuste poole.

Näib, et enamasti on ópiülekannet käsitlevate uuringute disain rajanenud skeemil, kus esmalt omandavad óppijad teoreetilise teadmise ning seejärel uuritakse, kas nende praktiline sooritus selle tulemusena paraneb. Kui lähtuda õpiülekande soodustamist käsitlevas peatükis kirjeldatud järeldusest, mille kohaselt õppija soov või suutlikkus tuletada üldisest üksikut on enamasti oodatust väiksem, siis pole ülekande madal tase selliste eksperimentide puhul ka üllatav. Mängu „Allikad” põhjal tehtud uuring lubab oletada, et hariduslikud mängud ja simulatsioonid osutuvad tõhusaiks just siis, kui nende disainis lähtutakse vastupidisest põhimõttest: esmalt esitatakse sihtülesandega struktuurilt sarnane praktiline ülesanne ning eeldatakse, et osalejad jõuavad saadud kogemuse põhjal üldistuseni, olgu siis mängu kestel või sellele järgneva arutelu käigus.

\section{Kokkuvõte}

Enamasti lähtutakse mängude ja simulatsioonide tõhususe hindamisel õpiülekande kriteeriumist: kas ja kuivõrd uue teadmise omandamine või samalaadse ülesande lahendamine uudses kontekstis tänu mängus osalemisele muutub. Mängupõhise õppe puhul on tegemist vähima suunamise strateegiaga, mistõttu tuleb arvestada nii selle strateegia tugevate kui ka nõrkade külgedega. Kuigi mängupõhise õppe eelised õppija motiveerimisel on üldteada, tuleb arvestada ka võimalusega, et õppureil ilmneb kognitiivse ülekoormuse probleem. Siiski demonstreeris kõnealune uuring, et õpiülekanne toimub ning osalejate akulturatsioonihoiakud muutuvad soovitud suunas.

Kui vaadelda toimunud muutuste võimalikke põhjusi, näeme, et peale mitmete seni tuntud õpiülekannet soodustavate tegurite võib mängu „Allikad” mõju selgitamisel toetuda veel kahele tegurile, millele tasuks järgnevates uuringutes keskenduda. Esiteks on võimalik, et künnismõisted, millele mäng oli üles ehitatud, toimisid osalejate mõtteskeemides omalaadsete siduvate sõlmpunktidena. Teiseks võis tõik, et mäng oli, kuigi sootuks teistel põhjustel, disainitud üsna metafoorsena, hõlbustada osalejatel metafoori ülevõtmist ja kasutamist uudses olukorras. See ei võimalda küll väita, et neist teguritest piisab teadmise omandamiseks ja selle ülekandeks, ent loodetavasti annab see hariduslike mängude uurijatele ja loojatele mõned lisapidepunktid edasisteks eksperimentideks. Küll aga lubab uurimus sedastada, et õpiotstarbelise mängu abil on võimalik kaasa aidata osalejate akulturatsioonihoiakute muutumisele. Võimalik, et mängu käigus 
omandatav õpisisu on n-ö tavameetoditega võrreldes napim, mistõttu on õppija võime omandatud teadmist meenutada ja uues situatsioonis kasutada sellevõrra tõhusam. Pidades silmas lõimumise arengukavas toodud eesmärki suurendada eestikeelsete püsielanike avatust ja kujundada nende hoiakuid (Lõimuv Eesti, 2014, lk 4), tasuks kaaluda hariduslike mängude kasutamist selle ülesandega tegelemisel.

\section{Tänusõnad}

Täname retsensente ja keeletoimetajaid sisukate tähelepanekute ja toetavate nõuannete eest.

\section{Kasutatud kirjandus}

Ainsaar, M., \& Beilmann, M. (2016). Üldised hoiakud sisserände suhtes. M. Ainsaar \& M. Beilmann (toim.), Eesti elanikkonna hoiakud kolmandatest riikidest sisserändajate suhtes Euroopa sotsiaaluuringu andmetes. Uuringu aruanne (lk 16-23). Tartu: Tartu Ülikool. Külastatud aadressil

http://www.yti.ut.ee/sites/default/files/www_ut/randehoiakute_raport_loplik.pdf.

Akin, E. (2015). What you gotta know to play good in the Iterated Prisoner's Dilemma. Games, 6(3), 175-190. doi: http://dx.doi.org/10.3390/g6030175

Arends-Tóth, J., \& van de Vijver, F. J. R. (2003). Multiculturalism and acculturation: Views of Dutch and Turkish-Dutch. European Journal of Social Psychology, 33(2), 249-266. doi: http://dx.doi.org/10.1002/ejsp.143

Aronson, K. M., \& Brown, R. (2013). Acculturation and social attitudes among majority children. International Journal of Intercultural Relations, 37(3), 313-322. doi: http://dx.doi.org/10.1016/j.ijintrel.2013.02.004

Barnett, S. M., \& Ceci, S. J. (2002). When and where do we apply what we learn? A taxonomy for far transfer. Psychological Bulletin, 128(4), 612-637.

doi: http://dx.doi.org/10.1037//0033-2909.128.4.612

Barradell, S. (2013). The identification of threshold concepts: A review of theoretical complexities and methodological challenges. Higher Education, 65(2), 265-276 doi: http://dx.doi.org/10.1007/s10734-012-9542-3

Bartlett, F. C. (1932). Remembering: A study in experimental and social psychology. Cambridge: Cambridge University Press.

Beilmann, M. (2016). Suhtumine eri päritolu sisserändajate rühmadesse. M. Ainsaar \& M. Beilmann (toim.), Eesti elanikkonna hoiakud kolmandatest riikidest sisserändajate suhtes Euroopa sotsiaaluuringu andmetes. Uuringu aruanne (lk 24-27). Tartu: Tartu Ülikool. Külastatud aadressil

http://www.yti.ut.ee/sites/default/files/www_ut/randehoiakute_raport_loplik.pdf.

Bergsteiner, H., Avery, G. C., \& Neumann, R. (2010). Kolb's experiential learning model: Critique from a modelling perspective. Studies in Continuing Education, 32(1), 29-46. doi: http://dx.doi.org/10.1080/01580370903534355 
Berry, J. W. (2006). Contexts of acculturation. In D. L. Sam \& J. W. Berry (Eds.), The Cambridge handbook of acculturation psychology (pp. 27-42). Cambridge: Cambridge University Press. doi: http://dx.doi.org/10.1017/CBO9780511489891

Berry, J. W., Poortinga, Y. H., Breugelmans, S. M., Chasiotis, A., \& Sam, D. L. (2011). Cross-cultural psychology: Research and applications (3rd ed.). Cambridge: Cambridge University Press. doi: http://dx.doi.org/10.1017/CBO9780511974274

Berry, J. W., \& Sam, D. L. (1997). Acculturation and adaptation. In J. W. Berry, M. H. Segall, \& C. Kagitçibasi (Eds.), Handbook of cross-cultural psychology: Social behavior and applications (Vol. 3, 2nd ed., pp. 291-326). Boston: Allyn and Bacon.

Bourhis, R. Y., Moïse, L. C., Perreault, S., \& Senécal, S. (1997). Towards an interactive acculturation model: A social psychological approach. International Journal of Psychology, 32(6), 369-386. doi: http://dx.doi.org/10.1080/002075997400629

Breugelmans, S. M., \& van de Vijver, F. J. R. (2004). Antecedents and components of majority attitudes toward multiculturalism in the Netherlands. Applied Psychology, 53(3), 400-422. doi: http://dx.doi.org/10.1111/j.1464-0597.2004.00177.x

Chi, M. T. H., \& VanLehn, K. A. (2012). Seeing deep structure from the interactions of surface features. Educational Psychologist, 47(3), 177-188. doi: http://dx.doi.org/10.1080/00461520.2012.695709

Chin, J., Dukes, R., \& Gamson, W. (2009). Assessment in simulation and gaming: A review of the last 40 years. Simulation \& Gaming, 40(4), 553-568. doi: http://dx.doi.org/10.1177/1046878109332955

Coffield, F., Moseley, D., Hall, E., \& Ecclestone, K. (2004). Learning styles and pedagogy in post-16 learning: A systematic and critical review. Learning and Skills Research Centre, 84. Retrieved from http://sxills.nl/lerenlerennu/bronnen/Learning\%20styles\%20by\%20Coffield\%20e.a..pdf.

Davies, P., \& Mangan, J. (2008). Embedding threshold concepts: From theory to pedagogical principles to learning activities. In R. Land, J. H. F. Meyer, \& J. Smith (Eds.), Threshold Concepts within the Disciplines. (pp. 37-50). Rotterdam: Sense Publishers.

Day, S. B., \& Goldstone, R. L. (2011). Analogical transfer from a simulated physical system. Journal of Experimental Psychology. Learning, Memory, and Cognition, 37(3), 551-567. doi: http://dx.doi.org/10.1037/a0022333

Day, S. B., \& Goldstone, R. L. (2012). The import of knowledge export: Connecting findings and theories of transfer of learning. Educational Psychologist, 47(3), 153176. doi: http://dx.doi.org/10.1080/00461520.2012.696438

Dudai, Y. (2007). Memory: It's all about representations. In H. L. Roediger, Y. Duday, \& S. M. Fitzpatrick (Eds.), Science of memory concepts (pp. 13-17). Oxford: Oxford University Press.

Ehala, M., \& Zabrodskaja, A. (2011). Interethnic discordance and stability in Estonia. Journal of Baltic Studies, 42(2), 213-237. doi: http://dx.doi.org/10.1080/01629778.2011.569068

Europe's migration crisis (2016). Human Rights Watch. Retrieved from https://www.hrw.org/tag/europes-migration-crisis.

Fowler, S. M., \& Pusch, M. D. (2010). Intercultural simulation games: A review (of the United States and beyond). Simulation \& Gaming, 41(1), 94-115.

doi: http://dx.doi.org/10.1177/1046878109352204 
Garris, R., Ahlers, R., \& Driskell, J. E. (2002). Games, motivation, and learning: A research and practice model. Simulation \& Gaming, 33(4), 441-467.

doi: http://dx.doi.org/10.1177/1046878102238607

Hager, P., \& Hodkinson, P. (2009). Moving beyond the metaphor of transfer of learning. British Educational Research Journal, 35(4), 619-638.

doi: http://dx.doi.org/10.1080/01411920802642371

Hardin, G. (1968). The tragedy of the commons. Science, 162(3859), 1243-1248. doi: http://dx.doi.org/10.1126/science.162.3859.1243

Helfenstein, S. (2005). Transfer: review, reconstruction, and resolution. Jyväskylä studies in computing 59. Jyväskylä: University of Jyväskylä.

Herfst, S. L., van Oudenhoven, J. P., \& Timmerman, M. E. (2008). Intercultural Effectiveness Training in three Western immigrant countries: A cross-cultural evaluation of critical incidents. International Journal of Intercultural Relations, 32(1), 67-80. doi: http://dx.doi.org/10.1016/j.ijintrel.2007.10.001

Hofstede, G. J., de Caluwé, L., \& Peters, V. (2010). Why simulation games work-in search of the active substance: A synthesis. Simulation \& Gaming, 41(6), 824-843. doi: http://dx.doi.org/10.1177/1046878110375596

Hung, W. (2013). Problem-based learning: A learning environment for enhancing learning transfer. New Directions for Adult and Continuing Education, 2013(137), 27-38. doi: http://dx.doi.org/10.1002/ace.20042

Isac, M. M., Maslowski, R., \& van der Werf, G. (2012). Native student attitudes towards equal rights for immigrants. A Study in 18 European Countries. Journal of Social Science Education, 11(1), 7-26.

doi: http://dx.doi.org/10.2390/jsse-v11-i1-1189

Kahneman, D. (2011). Thinking fast and slow. New York: Farrar, Straus and Giroux.

Kaminski, J. A., Sloutsky, V. M., \& Heckler, A. F. (2013). The cost of concreteness: The effect of nonessential information on analogical transfer. Journal of Experimental Psychology: Applied, 19(1), 14-29. doi: http://dx.doi.org/10.1037/a0031931

Kim, Y. Y. (2001). Becoming intercultural: An integrative theory of communication and cross-cultural adaptation. Thousand Oaks: SAGE Publications. doi: http://dx.doi.org/10.4135/9781452233253

Kirschner, P. A., Sweller, J., \& Clark, R. E. (2006). Why minimal guidance during instruction does not work: An analysis of the failure of constructivist, discovery, problem-based, experiential, and inquiry-based teaching. Educational Psychologist, 41(2), 75-86. doi: http://dx.doi.org/10.1207/s15326985ep4102_1

Kolb, D. A. (1984). Experiential learning: Experience as the source of learning and development. Englewood Cliffs: Prentice Hall.

Kosic, A., Mannetti, L., \& Sam, D. L. (2005). The role of majority attitudes towards out-group in the perception of the acculturation strategies of immigrants. International Journal of Intercultural Relations, 29(3), 273-288.

doi: http://dx.doi.org/10.1016/j.ijintrel.2005.06.004

Kruusvall, J., Vetik, R., \& Berry, J. W. (2009). The strategies of inter-ethnic adaptation of Estonian Russians. Studies of Transition States and Societies, 1(1), 3-24. Retrieved from http://htk.tlu.ee/stss/wp-content/uploads/2009/12/STSS_Kruusvall_Vetik_Berry.pdf. 
Kus-Harbord, L., \& Ward, C. (2015). Ethnic Russians in post-Soviet Estonia: Perceived devaluation, acculturation, well-being, and ethnic attitudes. International Perspectives in Psychology: Research, Practice, Consultation, 4(1), 66-81. doi: http://dx.doi.org/10.1037/ipp0000025

Laineste, L., Raus, T., Timmi, M., Vetik, R., \& Vihalemm, T. (2011). Rassi- ja võõravimm Eestis. Tallinn: Justiitsministeerium. Külastatud aadressil http://www.kriminaalpoliitika.ee/et/rassi-ja-vooravimm-eestis.

Lakoff, G. (1993). The contemporary theory of metaphor. In A. Ortony (Ed.), Metaphor and thought (2nd ed., pp. 202-251). Cambridge: Cambridge University Press. doi: http://dx.doi.org/10.1017/CBO9781139173865.013

Lakoff, G., \& Johnson, M. (1980). The metaphorical structure of the human conceptual system. Cognitive Science, 4(2), 195-208.

doi: http://dx.doi.org/10.1207/s15516709cog0402_4

Lobato, J. (2012). The actor-oriented transfer perspective and its contributions to educational research and practice. Educational Psychologist, 47(3), 232-247. doi: http://dx.doi.org/10.1080/00461520.2012.693353

Lõimuv Eesti 2020. Valdkondlik arengukava (2014). Tallinn: Kultuuriministeerium. Külastatud aadressil http://www.kul.ee/sites/kulminn/files/loimuv_eesti_2020.pdf.

Mayer, B. W., Dale, K. M., Fraccastoro, K. A., \& Moss, G. (2010). Improving transfer of learning: Relationship to methods of using business simulation. Simulation \& Gaming, 42(1), 64-84. doi: http://dx.doi.org/10.1177/1046878110376795

McCarthy, K. (1998). Adaptation of immigrant children to the United States: A review of the literature (working paper) (Vol. 3). New Jersey. Retrieved from http://crcw.princeton.edu/workingpapers/WP98-03-McCarthy.pdf.

McDaniel, M. A. (2007). Transfer: Rediscovering a central concept. In H. L. Roediger, Y. Dudai, \& S. M. Fitzpatrick (Eds.), Science of memory: Concepts (pp. 267-270). Oxford: Oxford University Press.

Meadows, D. L. (1999). Learning to be simple: My odyssey with games. Simulation \& Gaming, 30(3), 342-351. doi: http://dx.doi.org/10.1177/104687819903000310

Meyer, J. H. F., \& Land, R. (2005). Threshold concepts and troublesome knowledge (2): Epistemological considerations and a conceptual framework for teaching and learning. Higher Education, 49(3), 373-388. doi: http://dx.doi.org/10.1007/s10734-004-6779-5

Männamaa, I. (2015). FOUNTAINS: Table-top simulation game on acculturation strategies. Simulation \& Gaming, 46(1), 113-126. doi: http://dx.doi.org/10.1177/1046878115591248

Männamaa, I., \& Leijen, Ä. (2015). The Simulated Acculturation Model in the FOUNTAINS-Game. Simulation \& Gaming, 46(1), 98-112. doi: http://dx.doi.org/10.1177/1046878115591393

Männamaa, I., Vetik, R., \& Liiv, I. (2011). Mudeldusmäng Allikad. Juhend. Tartu: Integratsiooni Sihtasutus.

Navas, M., Rojas, A. J., García, M., \& Pumares, P. (2007). Acculturation strategies and attitudes according to the Relative Acculturation Extended Model (RAEM): The perspectives of natives versus immigrants. International Journal of Intercultural Relations, 31(1), 67-86. doi: http://dx.doi.org/10.1016/j.ijintrel.2006.08.002 
Nokes-Malach, T. J., \& Mestre, J. P. (2013). Toward a model of transfer as sense-making. Educational Psychologist, 48(3), 184-207. doi: http://dx.doi.org/10.1080/00461520.2013.807556

Park, J. (2015). Europe's migration crisis. Council on Foreign Relations. Retrieved from http://www.cfr.org/migration/europes-migration-crisis/p32874.

Perkins, D. N., \& Salomon, G. (2012). Knowledge to go: A motivational and dispositional view of transfer. Educational Psychologist, 47(3), 248-258. doi: http://dx.doi.org/10.1080/00461520.2012.693354

Petrie, H. G., \& Oshlag, R. S. (1993). Metaphor and learning. In A. Ortony (Ed.), Metaphor and thought (2nd ed., pp. 579-609). Cambridge: Cambridge University Press. doi: http://dx.doi.org/10.1017/CBO9781139173865.027

R Core Team. (2013). R: A language and environment for statistical computing. Vienna: R Foundation for Statistical Computing. Retrieved from http://www.r-project.org/.

Refugee crisis: European Commission takes decisive action (2015). European Commission, DG Migration and Home Affairs. Retrieved from http://ec.europa.eu/dgs/ home-affairs/what-is-new/news/news/2015/20150909_1_en.htm.

Rieber, L. P., Smith, L., \& Noah, D. (1998). The value of serious play. Educational Technology, 38(6), 29-37.

Rosalie, S. M., \& Müller, S. (2014). Expertise facilitates the transfer of anticipation skill across domains. The Quarterly Journal of Experimental Psychology, 67(2), 319-34.

Ross, B. H. (1989). Remindings in learning and instruction. In S. Vosniadou \& A. Ortony (Eds.), Similarity and analogical reasoning (pp. 438-469). Cambridge: Cambridge University Press. doi: http://dx.doi.org/10.1017/CBO9780511529863.021

Ruben, B. D. (1999). Simulations, games, and experience-based learning: The quest for a new paradigm for teaching and learning. Simulation \& Gaming, 30(4), 498505. doi: http://dx.doi.org/10.1177/104687819903000409

Sam, D. L., \& Berry, J. W. (2010). Acculturation: When individuals and groups of different cultural backgrounds meet. Perspectives on Psychological Science, 5(4), 472481. doi: http://dx.doi.org/10.1177/1745691610373075

Schoenfeld, A. H. (1999). Looking toward the 21st century: Challenges of educational theory and practice. Educational Researcher, 28(7), 4-14.

Shirts, R. G. (1995). Beyond ethnocentrism: Promoting cross-cultural understanding with BaFa BaFa. In S. M. Fowler \& M. G. Mumford (Eds.), Intercultural sourcebook: Cross-cultural training methods (pp. 93-101). Boston: Intercultural Press.

Simons, P. R. J. (1999). Transfer of learning: Paradoxes for learners. International Journal of Educational Research, 31(7), 577-589. doi: http://dx.doi.org/10.1016/S0883-0355(99)00025-7

Stephan, W. G., Renfro, C. L., Esses, V. M., Stephan, C. W., \& Martin, T. (2005). The effects of feeling threatened on attitudes toward immigrants. International Journal of Intercultural Relations, 29(1), 1-19. doi: http://dx.doi.org/10.1016/j.ijintrel.2005.04.011

Strabac, Z., \& Listhaug, O. (2008). Anti-Muslim prejudice in Europe: A multilevel analysis of survey data from 30 countries. Social Science Research, 37(1), 268-286. doi: http://dx.doi.org/10.1016/j.ssresearch.2007.02.004

Zagefka, H., González, R., \& Brown, R. (211). How minority members' perceptions of majority members' acculturation preferences shape minority members' own 
acculturation preferences: Evidence from Chile. British Journal of Social Psychology, 50(2), 216-233. doi: http://dx.doi.org/10.1348/014466610X512211

Tartakovsky, E. (2012). Factors affecting immigrants' acculturation intentions: A theoretical model and its assessment among adolescent immigrants from Russia and Ukraine in Israel. International Journal of Intercultural Relations, 36(1), 83-99. doi: http://dx.doi.org/10.1016/j.ijintrel.2011.02.003

Teder, M. (2015, 26. juuni). Uuring: pagulaste vastu on 42 protsenti Eesti elanikest. Postimees. Külastatud aadressil http://www.postimees.ee/3236833/uuring-pagulaste-vastu-on-42-protsenti-eesti-elanikest.

Thiagarajan, S. (2006). Barnga: A simulation game on cultural clashes (25th anniversary ed.). Boston: Intercultural Press.

Thijs, J., \& Verkuyten, M. (2014). School ethnic diversity and students' interethnic relations. British Journal of Educational Psychology, 84(1), 1-21. doi: http://dx.doi.org/10.1111/bjep.12032

Tun, J. K., Alinier, G., Tang, J., \& Kneebone, R. L. (2015). Redefining simulation fidelity for healthcare education. Simulation \& Gaming, 46(2), 159-174. doi: http://dx.doi.org/10.1177/1046878115576103

Verkuyten, M., Thijs, J., \& Sierksma, J. (2014). Majority children's evaluation of acculturation preferences of immigrant and emigrant peers. Child Development, 85(1), 176-191. doi: http://dx.doi.org/10.1111/cdev.12111

Vetik, R. (2015). Eesti riigiidentiteet: eestivenelaste kuuluvustunne ja eestlaste kaasamisvalmidus. Eesti ühiskonna lõimumismonitooring 2015. Uuringu aruanne (lk 24-35). Tallinn: Kultuuriministeerium. Külastatud aadressil http://www.kul.ee/sites/kulminn/files/2peatykk.pdf.

Vezzali, L., Capozza, D., Stathi, S., \& Giovannini, D. (2012). Increasing outgroup trust, reducing infrahumanization, and enhancing future contact intentions via imagined intergroup contact. Journal of Experimental Social Psychology, 48(1), 437-440. doi: http://dx.doi.org/10.1016/j.jesp.2011.09.008

Väli, R. (2014). Teadmise ülekanne Allikate mängu põhjal (lõputöö). Tartu Ülikool, Viljandi. Külastatud aadressil http://hdl.handle.net/10062/41612.

Wainess, R., Koenig, A., \& Kerr, D. (2011). Aligning instruction and assessment with game and simulation design. CRESST report 780. Los Angeles: The National Center for Research on Evaluation, Standards, and Student Testing. Retrieved from http://files.eric.ed.gov/fulltext/ED520432.pdf.

Ward, C., \& Masgoret, A.-M. (2008). Attitudes toward immigrants, immigration, and multiculturalism in New Zealand: A social psychological analysis. International Migration Review, 42(1), 227-248. doi: http://dx.doi.org/10.1111/j.1747-7379.2007.00119.x

Wilcox, H. C., Kellam, S. G., Brown, C. H., Poduska, J. M., Ialongo, N. S., Wang, W., \& Anthony, J. C. (2008). The impact of two universal randomized first- and second-grade classroom interventions on young adult suicide ideation and attempts. Drug and Alcohol Dependence, 95(1), 60-73. doi: http://dx.doi.org/10.1016/j.drugalcdep.2008.01.005

Wouters, P., van Nimwegen, C., van Oostendorp, H., \& van der Spek, E. D. (2013). A meta-analysis of the cognitive and motivational effects of serious games. Journal of Educational Psychology, 105(2), 249-265. doi: http://dx.doi.org/10.1037/a0031311 


\title{
The impact of an educational game on participants' acculturation attitudes
}

\author{
Ivar Männamaa $^{\mathrm{a} 1}$, Aurika Komsaare ${ }^{\mathrm{a}}$, Äli Leijen ${ }^{\mathrm{b}}$ \\ ${ }^{a}$ University of Tartu, Viljandi Culture Academy \\ ${ }^{b}$ University of Tartu, Institute of Education
}

\section{Summary}

School-aged refugee children form a significant part of the educational system and pose many challenges for the recipient countries. Attitudes and acculturation preferences of peers from the majority population have been found to be an important factor in improving education for students from immigrant families (Isac et al., 2012; Kosic et al., 2005). Previous studies have demonstrated that game-based learning can have positive effects on students' motivation and attitudes. While several factors affecting the impact of games on cognitive learning outcomes have been identified, little research has addressed the possible impact on acculturation attitudes. However, it is known that learning transfer from source to target is rare. This paper investigates the impact of an experience acquired by playing the educational game FOUNTAINS (Männamaa, 2015) on the acculturation preferences/attitudes of game participants. FOUNTAINS has been translated into more than ten languages by Fall 2015.

The efficiency of game-based learning has been a topic of interest to many educationalists (Ruben, 1999; Wouters et al., 2013). No matter what forms of knowledge, skills or attitudes are intended to be acquired, game facilitators want the participants to apply what they have learned beyond the original play-session context. Such ability of the learner to extend what has been learned in one context to new contexts is known as learning transfer (Nokes-Malach \& Mestre, 2013; Perkins \& Salomon, 2012). Though learning transfer has been studied quite intensely, the question of when (and if at all) the far transfer occurs has not seen much progress.

In the current research, participants of the game were expected to understand a general principle by playing a metaphoric game and transfer the same principle to the acculturation attitudes. Before FOUNTAINS was launched two studies were conducted to identify its possible impact on participants' attitudes (Männamaa \& Leijen, 2015; Väli, 2014). As the results were encouraging, we were curious to find out whether the difference

Viljandi Culture Academy, Posti 1, 71004 Viljandi, Estonia; ivarman@ut.ee 
between the groups was accidental or if the game really worked. Doubts arouse for two major reasons. Firstly, the transfer of learning from one context to another seems to appear seldom. Secondly, the efficiency of gamebased learning as experiential learning has been questioned on a broader basis (Kirschner et al., 2006).

\section{Method and participants}

To address the research question, a quasi-experiment (groups were not randomised) was conducted. The experiment consisted of a pre-test, an intervention (game-session), and a post-test. To assess the change in preferences, an identical 12-item Likert-scale questionnaire was filled out. In total 131 participants took part in the survey (age range 17-24). Two groups were formed: one participated in the FOUNTAINS game (test group, $n=82$ ), whereas the other did not (control group, $n=49$ ). Both groups completed the questionnaire twice; the test group shortly before the game and a re-test about ten days after that. Raw data gathered during a previous study (Väli, 2014) was included in the current study.

All participants completed a 12-item questionnaire, including both positively and negatively keyed items. A Likert scale from 1-10 was used (ranging from "I strongly disagree" to "I strongly agree"). The score is calculated by totalling the responses of all twelve items. One end of the scale indicated respondents' support for the idea of cultural integration, at the other end, rather to assimilation or marginalisation of immigrants. Statements were based on four general principles:

1) It is important both to stand by one's beliefs and find common ground with other parties.

2) Access to resources may improve even if the borderlines between groups remain intact.

3) In the case of integration, it is important to consider the agents' wish to participate in the decision-making processes.

4) The topic of integration is accompanied by controversies, for example between the wish to retain one's original qualities and to gain access to resources.

\section{Game}

The simulation-game FOUNTAINS was used as intervention. FOUNTAINS is a table-top simulation game designed as a study aid to enhance comprehension of cultural integration processes. Participants must find 
ways to preserve their own comprehensive culture while providing other groups access to resources. A more explicit explanation of the model behind the game has been published previously (Männamaa \& Leijen, 2015). A game-session takes approx. 100 minutes in total: briefing 10 minutes, simulation 50 minutes, and debriefing 40 minutes.

\section{Results}

Results indicate a shift in acculturation attitudes after the game. A significant difference in the scores of the pre- and post-tests of the test-group was found $(\mathrm{t}=-1.73, \mathrm{p}=.043)$. This suggests that playing the FOUNTAINS does have an effect on acculturation attitudes. Our results suggest that after playing the game the preferences of the participants who attended the game agree more with the statements supporting the idea of cultural integration.

\section{Conclusion}

Although the process of learners' acquisition and application of knowledge has received much attention from educationalists and cognitive scientists, there is no agreement on when and if learning transfer takes place at all. Still, the efficiency of a simulation game is usually evaluated against just one criterion: Does the ability of the participants to perform better in a novel situation increase as a result of the tasks experienced during the game. Gamebased learning is an instructional strategy of minimal guidance; therefore, both the strengths and weaknesses of such strategies should be considered. Though motivational aspects of game-based learning are well known, the participants could face the problem of cognitive overload. Two options were discussed that might help to overcome this: Firstly, focusing on threshold concepts (Barradell, 2013) that serve as node-points in the conceptual map, and secondly, including elements in the design that stimulate the formation of metaphors (Lakoff \& Johnson, 1980). We do not claim that including these elements in game design is a sufficient condition for ensuring knowledge acquisition and transfer, but on theoretical grounds they can provide a valuable resource for further discussion. Though learning by playing may set some limits to the quantity of acquired knowledge, it seems to ease the further retrieval and implementation of the lessons learned.

Keywords: acculturation attitudes, change of attitudes, educational games, game-based learning, learning transfer, simulation/game Fountains 